\title{
Development of On-line Analytical Method for Hydrogen in Molten Steel at Vacuum Degassing Process
}

\author{
Yasuhiro Hayakawa, Akihiro Ono, Masao Saeki, \\ Kengo SENOO and Hideaki KimurA
}

\begin{abstract}
Synopsis :
Degassing operation in the steel making process is important in the production of low-hydrogen steel. The conventional analytical method for hydrogen in molten steel with sampling using a quartz tube takes a long time, and has insufficient accuracy. A direct analytical method for hydrogen in molten steel has been developed to solve these problems. In this system, a refractory probe is immersed in the molten steel and inert gas is blown through it into the molten steel. The hydrogen concentration in molten steel is then continuously measured by recovering samples of gas that has reached equilibrium in floating upward to a specified level in the ladle. This new analytical system is installed at the RH vacuum degasser of the steel making plant, and is being tested for its application to commercial operation. During degassing operation, the analytical values obtained by the proposed method well agree with those by the conventional method in the low concentration range. On the other hand, the proposed analytical method yields higher values in the high concentration range, probably because of the escape of hydrogen from the sample during and after sampling in the conventional method. The new analytical method can continuously measure the hydrogen concentration of molten steel in $2.5 \mathrm{~min}$, about one-tenth of the analytical time of the conventional method.
\end{abstract}

Key words : on-line analysis; hydrogen in molten steel; degassing process; equilibrium of hydrogen between molten steel and inert gas; refractory probe for hydrogen sampling.

\section{1. 緒言}

溶鋼の脱ガス処理は师板などの低水素鋼製造において 重要なプロセスであり，この精鍊過程における脱水素の

挙動を正確かつ进速に把据できる分析技術の確立が要請 されている.

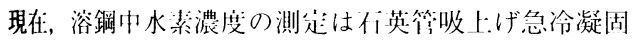
法(ピンサンプリング法)で行われている。このナ法は

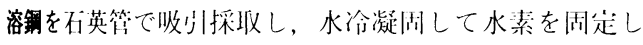

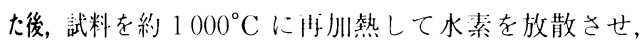

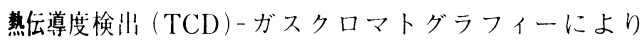
定量を行う。しかし, 仼料の採攻や冷却時の水素の散逸 が䅉視できず，分析に $10 \mathrm{~min}$ 以上を要する問題がある。
近年，新たな溶鋼サンプラーとして真空二重鉄管製1) あるいは鉄管封入石英ガラス管式サンプラー ${ }^{2)}$ などが 開発され，従来に比べ迅速で正確さの高い水素分析值が 得られるようになってきた。しかしこれらのオ法では 時時刻刻变化する脱ガス処理過程中の水素濃度をリアル タイムに測定することはできない.

そこで著者らは，溶鋼中水素のオンライン・リアル夕 イム分析法の開発を目的に，大坪らによる電気炉での基 礎实験 ${ }^{3)}$ を引き継ぎ，実操業下の RH 脱ガス処理プロ セスにおいて実灯試験を行ってきた4)．本法は溶鋼中に 不活性ガスを吹き込み，吹き込んだガスと溶鋼との間で の気液平衡に基づいて水素濃度を測足するものである. この測走方法はアルミニウム精鍊で用いられている

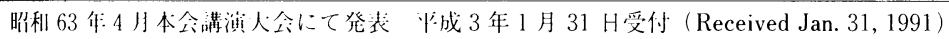

* 新H本製鉄(株)先端技術研究所 (Advanced Materials \& Technology Research Laboratories, Nippon Steel Corp., 1618 Ida Nakahara-ku Kawasaki 211)

*2 新H本製鉄(株)先端技術研究听 理博 (Advanced Materials \& Technology Research Laboratories, Nippon Steel Corp.)

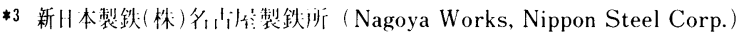


Telegas 法 ${ }^{55)}$ を基本とするが，水素の搪散速度および 融点の異なる溶鋼を対象に，最適な水素回収方法㧍よび 分析条件の確浐を行ってきた。

-一方，1988 年に Pt.ESSERS らによって Telegas 法をほ ぼそのまま適用した溶鋼中水素のオンライン分析方法が 報告された ${ }^{7)}$ が，この方式のガス回収方法を用いる限り リアルタイム分析を行うことは困難である。

本報では，著者らが新たに開発した溶鋼中水素オンラ イン分析法の実炉試験絬果，および実操業下の RH 脱 ガス処理プロセスにおける脱水素挙動の測定結果につい て報告する。

\section{2. 測 定 原 理}

水素のような 2 原子分子気体が溶鉄に溶解する場令, それらは解離, 独立し，2 湖の原子に分かれて溶解する. 温度，压力が一定の条作下に扔いては，この溶解成心に おける溶鉄中への水素の溶解度は，その分压の平方根に 比例する (Sieverts の法則)。このとき，溶鉄と気相と の閂には化学平衡が成立しているから, 気相中の水素分 压を $P_{\mathrm{H}_{2}}$, 溶解水素の活量を $a_{\mathrm{H}}$ とすると, 平衡定数 $K$ は次式で表すことができる。

$$
K=a_{\mathrm{H}} / \sqrt{\mathrm{P}_{\mathrm{H}_{2}}} \text {. }
$$

ここで，水素の溶解度はきわめて小さく，その活量倸数 $f$ は, $f \doteqdot 1$ で近似することができるから, 溶鉄中水素 濃度を $[\mathrm{H}](\mathrm{wt} \%)$ とすると，（1）式は次のように書き 換えることができる.

$$
\begin{aligned}
& K=a_{\mathrm{H}} / \sqrt{P_{\mathrm{H}_{2}}}=f[\mathrm{H}] / \sqrt{P_{\mathrm{H}_{2}}} \fallingdotseq[\mathrm{H}] / \sqrt{P_{\mathrm{H}_{2}}} \\
& \therefore \quad[\mathrm{H}]=K \sqrt{P_{\mathrm{H}_{2}}} \cdots \cdots \cdots \cdots \cdots \cdots \cdots \cdots \cdots \cdots \cdots \cdots \cdots \cdots \cdots \cdots \cdots \cdots \cdots \cdots \cdots \cdots
\end{aligned}
$$

平衡定数 $K$ は，温度の関数として表され，現在推奨さ れている値8)は次のと抄りである.

$$
\log K=-1905 / T-1.591
$$

ここで，Tは溶鉄の温度（絶対温度）である。

本分析力法は上記の原理に基づき，溶鋼中に一定流量 の不活性ガスを吹き込み，溶䤱と头衡に達したガスを回 収してその水素分压を測尘し，（2），（3)式を用いて溶 鋼中水素濃度を決定するものである.

\section{3. 開発した水素分析システム}

\section{$3 \cdot 1$ 分析システム}

新たに開発した溶鋼中水素オンライン分析システムの RH 脱ガス処理設備への設置概略汹を Fig. 1 に示す. 本システムは溶鋼に浸漬するガス回収用耐火物製プロー ブ，プローブの昇降装置および加熱装置，Ar ガス供給 装置，回収ガス分析装置などから構成される。

$\mathrm{RH}$ 脱ガス处理過程中の溶鋼にあらかじめ加熱したプ

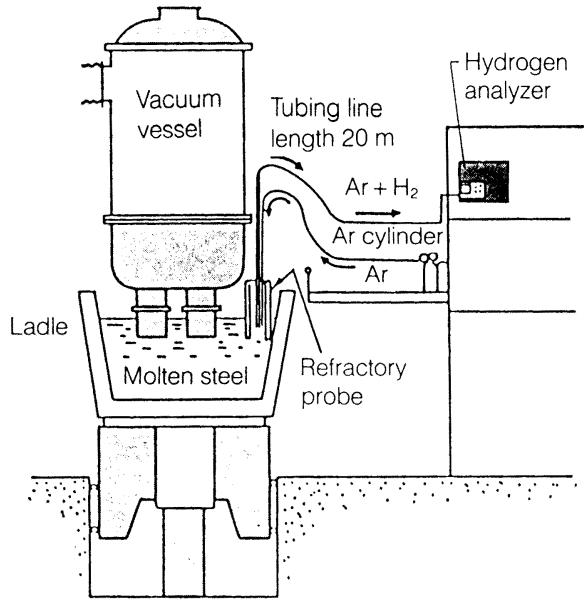

Fig. 1. Schematic diagram of direct analytical system for hydrogen in molten steel at $\mathrm{RH}$ process.

ローブを浸漬し，一定流量に制御した Ar ガスを吹き込 む。溶鋼中を一定距離浮上し, 溶鋼中の水素と平衡に達 した Ar ガスはプローブ上部より回収され，約 $20 \mathrm{~m} の$ ガス配管（ステンレス鋼製，内栙 $4 \mathrm{~mm} \phi$ )を通って操作 公に設置した分析装置まで搬送される。回収ガス分析装 置には TCD-ガスクロマトグラフィー（泉津製作所製 $\mathrm{GC}-8 \mathrm{~A}$, 分離カラム: 内往 $3 \mathrm{~mm} \phi$, 长さ $1.5 \mathrm{~m}$, 充填 剤: モレキュラーシーブ $5 \mathrm{~A}$, カラム温度 : $50^{\circ} \mathrm{C}, \mathrm{Ar}$ キャリアガス流量 : $150 \mathrm{ml} / \mathrm{min}$ ) を採用した。測定結果 はデータ处理用のパーソナルコンピューター（日本電気 製 PC-9801 VM21）に取り达み，脱ガス处理過程中の溶 鋼中水素濃度を CRT 上に裴示する。

\section{$3 \cdot 2$ プローブの材質および構造}

溶鋼へのガス吹込みおよびガス四収のために用いるプ ローブには，十分な耐久性が要求される。そこで，製鉄 の分野で耐火物としてよく用いられている $\mathrm{SiO}_{2}$, $\mathrm{MgO}-\mathrm{C}, \quad \mathrm{MgO}-\mathrm{Cr}_{2} \mathrm{O}_{3}, \quad \mathrm{Al}_{2} \mathrm{O}_{3}-\mathrm{MgO}, \quad \mathrm{Al}_{2} \mathrm{O}_{3}-\mathrm{SiO}_{2}$, $\mathrm{Al}_{2} \mathrm{O}_{3}-\mathrm{C}, \mathrm{Al}_{2} \mathrm{O}_{3}-\mathrm{SiC}, \mathrm{SiC} に つ い て, カ ゙ ス$ 回収用プロー ブとしての耐熱衝繋性，柎侵食性の検讨を行った。

その結果, $\mathrm{MgO}-\mathrm{C}$ 系の材質か酎熱衝慗性, 酎侵食性 ともに最も優れていたが, 加、性が恵くプローブへの成 型が网難であった。一方， $\mathrm{Al}_{2} \mathrm{O}_{3}-\mathrm{C}$ 系の材質は耐熱衝 撃性，耐侵食性とともに加に性も郎好であったが，加熱 により CO ガスの大量発生が垫められた。そこで，射 熱衝慗性の点でやや劣るが，耐侵食性が良好で加1性に 優れた $\mathrm{Al}_{2} \mathrm{O}_{3}-\mathrm{SiC}$ 系の材質をプローブ材啠として採用 することに決定した。 


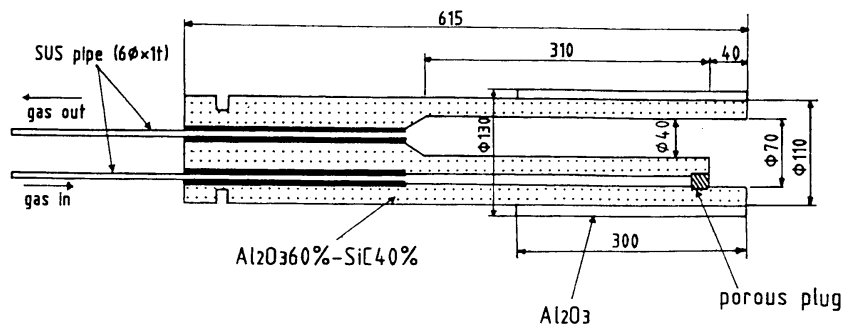

Fig. 2. Schematic diagram of the probe for gas injection and collection.

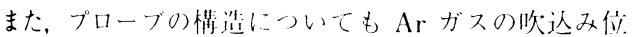
置およびガス㺫收位，あるいは内行䅡などについて

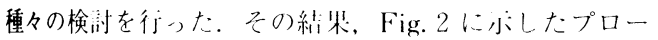

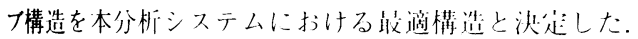
溶敇への $\mathrm{Ar}$ ガスの炊迟みはプローブ内榫に没けた ポーラスプラグ(多孔筫臫火物, $\mathrm{Al}_{2}\left(\mathrm{O}_{3}, 94 \%-\mathrm{SiO}_{2} 4 \%\right.$ $\left.\mathrm{ZrO}_{2} 2 \%\right)$ からト们きに行い，溶制と衡に達したガス をプローブト溂より㺫收するう式である。また，スラグ ラインは䖪度を保のために $\mathrm{Al}_{2} \mathrm{O}_{3}$ で被覆した。さらに，

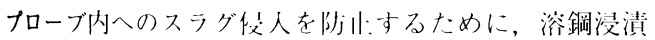
時にはプローブ先端に鉄製のキャップを取り付けた。ま た，酎熱衝慗性を緩利し、プローブけの水分を除去する

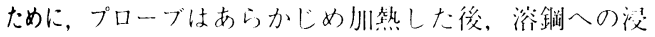
漬を行った。

\section{4. 実験結果および考察}

\section{$4 \cdot 1$ 最適分析条件}

$4 \cdot 1 \cdot 1$ ガス父泡徐

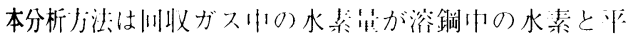

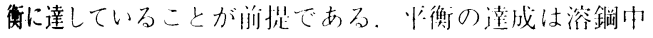

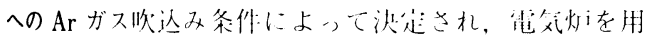

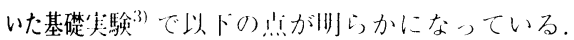

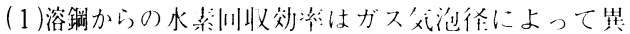

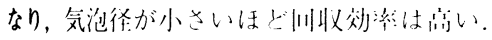

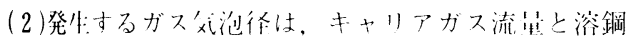
への吹认みノズルの外胙によって渗往され，ガス流革

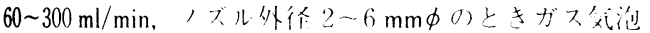
烽は約 $10 \mathrm{~mm} \phi$ ある。.

(3)外栙 $6 \mathrm{~mm} \phi$, 以行 $1.2 \mathrm{~mm} \phi$ 0吹迟み) ズルを用 い, 流量 $50 \mathrm{ml} / \mathrm{min}$ でキャリアガス老涳鐗ゆに40 mm

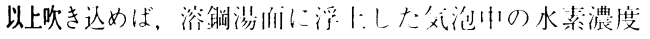
はほほ平衡值に篎しい。

上記の結果は、梁。孔のガス吹迟みノズルを朋いた場

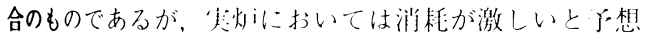
されたため, ノズル少端にポーラスプラグを取り付けた 吹込みノズルを採川した。
ガス気泡径が晎なると，水素回収効率が変化すること が基礎垁験から明らかであり，ポーラスプラグを用いた 場命のガス気泡径を求める必要がある。ポーラスプラグ のような多孔質板から発生するガス気泡径 $d$ は，小出

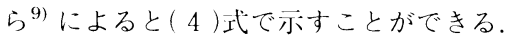

$$
d\left(\frac{g \rho}{\sigma \delta}\right)^{1 / 3}=1.35\left(F r / W e^{0.5}\right)^{0.278}
$$

ここで, $g:$ 重力加速度 $\left(980 \mathrm{~cm} / \mathrm{s}^{2}\right)$

$\rho:$ 液体の密度 $\left(7.17 \mathrm{~g} / \mathrm{cm}^{310)}\right)$

$\sigma:$ 液体の表面張力（1600 dyn $/ \mathrm{cm}(\mathrm{O}=50 \mathrm{ppm}$ とし $\left.\tau)^{11)}\right)$

$\delta:$ 孔径 $(15.3 \mu \mathrm{m}$ (ポーラスプラグの平均孔径 $))$

$F r: u / \sqrt{g \delta}$ (フルード数)

$W e: \delta u^{2} \rho / \sigma$ (ウェーバー数)

ただし， $u$ は流速であり，吹込み流量を $Q$ ，ポーラス プラグの細孔倜数を $n$ として，（５）のように表される.

$$
u=\frac{Q}{n(\delta / 2)^{2} \pi}
$$

さらに，溶鋼中に吹き迟まれたガスが常温から $1600^{\circ} \mathrm{C}$ に加熱される熱膨陙を考虑すると, 溶鋼中で発生するガ 又父泡径 $d$ は次のように求まる.

$$
d=0.87(\mathrm{~cm})
$$

溢鋼中に吹き迟まれたガスは溶鋼中を浮上する閒に凝集 するため，実際に回收されるガスの気泡従は(6)で示し な优よりも大きいと考えられる。

以は（の結果は、ポーラスブラグを用いて殓鋼へのガス 吹迟みを行った場令に扔いても，単一孔ノズルを用いた 場令とほぼ间等のガス気泡往が得られることを示してい z.

\section{$4 \cdot 1 \cdot 2$ ガス吹込み流量}

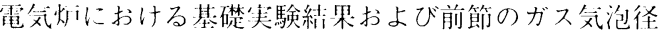
汁算結果を踏まえ，是炉に打いて溶鋼中への $\mathrm{Ar}$ キャリ アガス吹认み条件の検討を行った。ガス流量の影響を調 べるために，脱ガス処理過程中の溶鋼湯面下 $50 \mathrm{~mm}$ の 深さから, 種々の流量で Ar ガスを吹き込み, 回收ガス の分析を行った。その結果を Fig. 3 に亦す。㑗中には, 


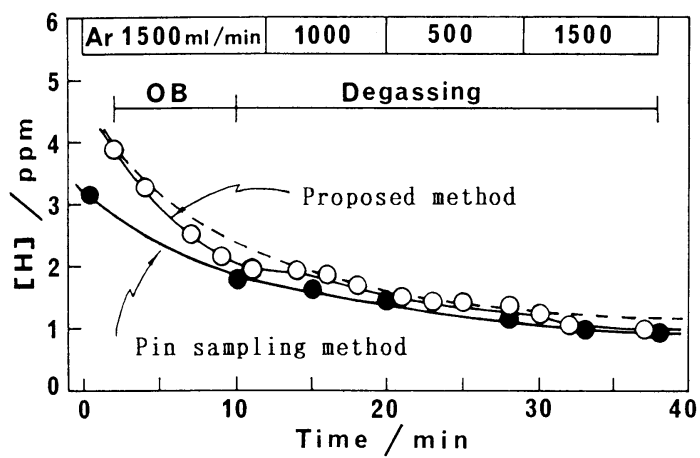

Fig. 3. Effect of injection gas flow rate on analytical results.

通常门程管理のために用いられているピンサンプリング 法による分析結果を併記した。この実験は脱ガス処理過 程中に行ったため, 時間経過とともに溶鋼中水素濃度は 減少している.

脱ガス処理開始值後に，ピンサンプリング法に比べ本 法による分析值が高值を示すが, これはピンサンプリン グ法における試料採取時の水素の散逸が原因であると考 えられる。水素散逸量を正確に評価することが困難なた め, 水素濃度の真值は不明であるが, 本法における最初 の分析値から外挿すると, 溶鋼中水素濃度は点線のよう に推移していると考えられる。すなわち, 回収ガス中の 水素量が溶鋼との間で平衡関係にあるならば, 水素濃度 は点線上を推移する。

$\mathrm{Ar}$ ガス吹达み流量が $500 \mathrm{ml} / \mathrm{min}$ あるいは 1000 $\mathrm{ml} / \mathrm{min}$ のときの分析值は, ほぼ点線上を推移し, プロー ブ内溶鋼と回収ガスとの閏に平衡が達成されていると考 えられる。しかし，吹込み流量が $1500 \mathrm{ml} / \mathrm{min}$ と大き くなると, 点線に比べ分析值の減少公配が大きくなる. これは，吹达み流量が過剩になったことで，プローブ内 の溶鋼が吹达みガスによって脱水素文伈を生じ，取鍋内 金体の溶鋼中水素濃度を这映しなくなるためであると考 えられる．繰り返し実験を行ってもほぼ同様の結果が得 られ，取鍋内金体の溶鋼中水素濃度を反映するには， $1000 \mathrm{ml} / \mathrm{min}$ 以下のガス流量が適していた。

本法では，回収ガスを短時開で分析装置まで搬送す る必要があり，溶鋼へのガス吹込み流量はできる限り大 流量であることが望ましい。この点を考虑し， 1000 $\mathrm{ml} / \mathrm{min}$ をキャリアガス流量として決定した。

$4 \cdot 1 \cdot 3$ ガス吹达み深さ

ガス流量とともに，浴鋼へのガス吹込み深さが平衡の 達成に影響を及ぼす。そこで, $1000 \mathrm{ml} / \mathrm{min} の \mathrm{Ar}$ ガス

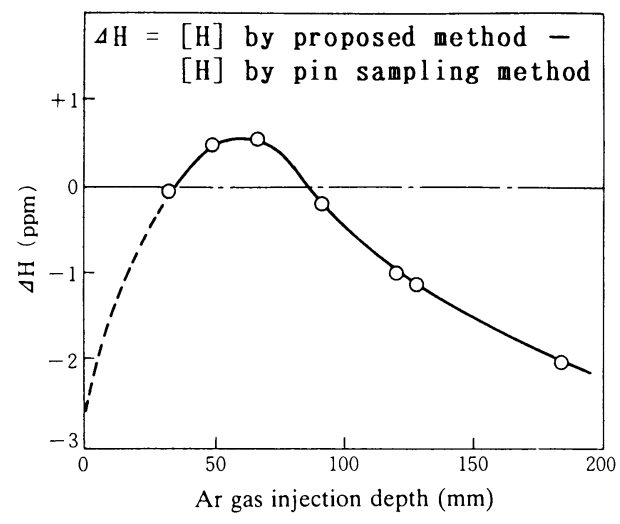

Fig. 4. Effect of bubble ascent distance on analytical results.

吹込み流量において，溶鋼中への吹込み深さを変化させ て回収ガスの分析を行った。同一鋼種, 同一条件下で行っ た実験のうち，ピンサンプリング法による分析值が 3 $\mathrm{ppm}$ を示したときの，本法とピンサンプリング法との 分析値の差を Fig. 4 に示す.

ガス吹込み深さが 40〜80 mm の範囲のとき，本法に よる分析值はピンサンプリング法に比べ最大 $0.5 \mathrm{ppm}$ 高值を示した。これはピンサンプリング法による水素の 散逸が原因であると考えられる．吹込み媣さがさらに深 くなると，しだいに分析値は低值を示す傾问にある。こ れは，吹込み深さの増大とともにプローブ内溶鋼の置換 が生じにくくなり, 吹込みガスによる脱水素文応が進行 することが原因と考えられる. $40 \mathrm{~mm}$ 以下の吹込み深 さについては実験を行っていないが, 吹込み深さが浅く なると溶鋼との平衡が達成されにくくなることが基礎実 験から明らかである.すなわち，吹达み深さが浅くなる ほど点線で示したように低值化傾问が大きくなると考え られる. 以上の結果より, 溶鋼中への $\mathrm{Ar}$ ガス吹迟み深 さを 40〜80 $\mathrm{mm}$ に決定した.

\section{$4 \cdot 2$ 回収ガス中の共存ガスの影翌}

本法では分析所要時閏を短縮するために，回収ガス分 析装置として用いたガスクロマトグラフの操作条件を $\mathrm{Ar}$ キャリアガス流量 $150 \mathrm{ml} / \mathrm{min}$, ガス分離カラム長 $1.5 \mathrm{~m}$ に選定した。この条作での分析所要時間は 2.5 $\mathrm{min} /$ 回であり, 回収ガスの主成分である $\mathrm{H}_{2}, \mathrm{O}_{2}, \mathrm{~N}_{2}$ の 分離定量が行える. しかし, 回収ガス中に他の成分が混 入されていた場合，分離カラム内に残伱し，その後の分 析に影響を与える叮能性があった。

そこで，溶鋼からの回収ガスを配管途中でガス採取ビ ンにより採取し，其存するすべてのガス成分の定量を 
Table 1. Analytical results of coexisting components in the collecting gas ( $\mathrm{vol} \%)$.

\begin{tabular}{c|c|c|c|c|c|c}
\hline $\begin{array}{c}\text { Degassing } \\
\text { time (min) }\end{array}$ & $\mathrm{H}_{2}$ & $\mathrm{CO}$ & $\mathrm{CO}_{2}$ & $\mathrm{~N}_{2}$ & $\mathrm{O}_{2}$ & $\mathrm{Ar}$ \\
\hline 5 & 6.37 & 5.44 & 1.12 & 7.78 & 0.25 & 79.04 \\
9 & 1.04 & 1.05 & 0.90 & 6.37 & 0.25 & 90.39 \\
18 & 0.18 & 1.63 & 1.34 & 6.91 & 0.21 & 89.73 \\
\hline
\end{tabular}

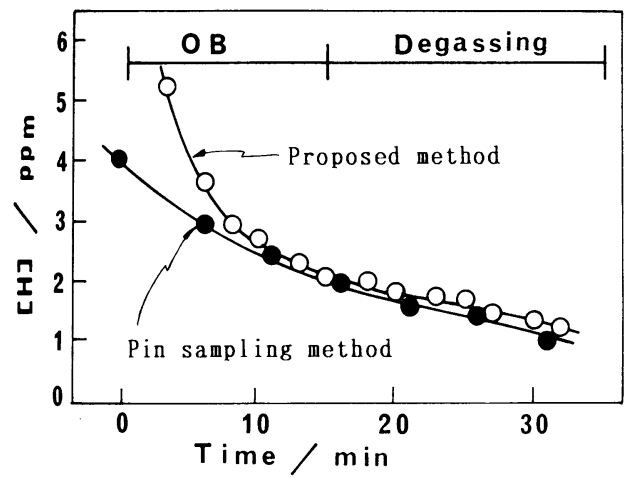

Fig. 5. Analytical results of the hydrogen content in molten steel in degassing process.

行ったその結果を Table 1 にホすす。検出されたガス 成分は $\mathrm{H}_{2}$ 以外に $\mathrm{CO}, \mathrm{CO}_{2}, \mathrm{~N}_{2}, \mathrm{O}_{2}$ 抢よび $\mathrm{Ar}$ であ ク，ガスクロマトグラフ测走に影響を!子える成分は CO たけであった。そこで，ガスクロマトグラフの計量管 直前に $\mathrm{I}_{2} \mathrm{O}_{5}$ ( $\mathrm{LECO}$ 社製 Schutze 試薬) カラムを設け C0ガスの除上を行った。このときカラム内では，

$\mathrm{I}_{2} \mathrm{O}_{5}+5 \mathrm{CO} \rightarrow \mathrm{I}_{2}+5 \mathrm{CO}_{2}$

の友迈が生に゙, $\mathrm{CO}$ は $\mathrm{CO}_{2}$ に変換される。発生した $\mathrm{CO}_{2}$ は, 分離カラム巾のモレキュラーシーブで吸着さ れ, 分析対象ガスから除かれる.

また，他のガス成分については，分離カラムで分離さ れ水素分析に影艟を!j立ないことを確認した。

\section{$4 \cdot 3$ 眖ガス処理過程中の溶鋼中水素濃度分析結果}

$\mathrm{Al}_{2} \mathrm{O}_{3}-\mathrm{SiC}$ 系のプローブを脱ガス処理過程中の浴鋼 に浸清し, Ar ガス吹込み流量 $1000 \mathrm{ml} / \mathrm{min}$, 吹达み樑 さ $50 \mathrm{~mm}$ の条作で溶铜中水濃度の分析を行ったとき の分析絬果の-例を Fig. 5 に亦す。㭎中にはピンサン プリング法による分析优も併䛉した。

脱ガス処理開始迪後に，本法はピンサンプリング法に 比べ高值を亦したが, 脱ガス処理 $10 \mathrm{~min}$ 以降は, 本法 による分析值とピンサンプリング法による分析值はほほ 一致した結果をぶした。

同様の実験を 6 回行ったときの，本法による分析値と ピンサンプリング法による分析值との相関 $(n=34)$ を

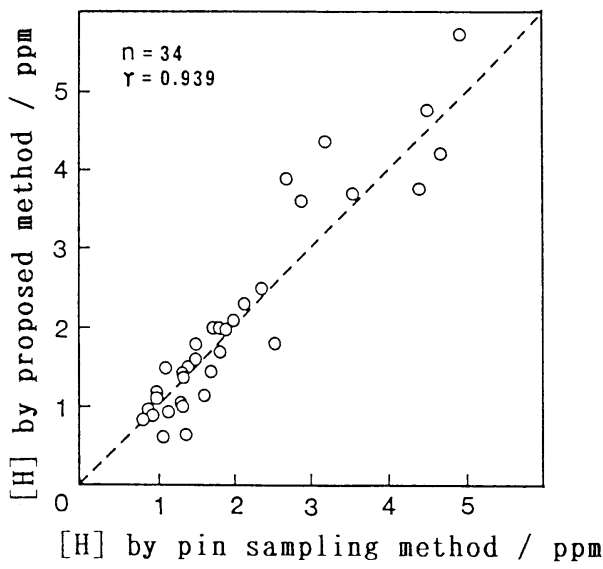

Fig. 6. Relation between the analytical values by proposed method and those by pin sampling method.

Fig. 6 に示す．両者の相関係数 $r$ は 0.939 であったが, 高濃度域になるほど分析值の差が増大し，本法による分 析值がピンサンプリング法による分析值に比べ高値を示 す傾们にある。

サンプリング時の水素の散逸を抑制し，信頼性が高い とされている真空 - - 重鉄管製サンプラー (LeyboldHeraeus 社製 ESK サンプラー) による测定結果とピン

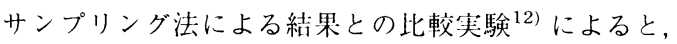
ピンサンプリング法は試料採取から急冷するまでの閒 の水素の散逸が無視できず，低值を与えることが示され ている.しかし， 1 2 ppm 程度の低濃度域では, サン プラーに含まれる水分のピックアップの影響が現れ，ば らつきつつも真値に近い值を示すとされている．

このことから考えると, 低濃度域でピンサンプリング 法による分析值とほぼ一致し，高濃度域では高値を示す 傾问にある本法は，ピンサンプリング法に比べ，より正 確な溶鋼中水素濃度值を示していると考えることができ る.

\section{$4 \cdot 4$ 分析精度, 時間}

本法の分析精度を調べるために，脱ガス処理終了後も 引き続いてプローブを溶鋼中に浸漬し, 回収ガスの分析 を行った.そのときに得られた分析結果を Fig. 7 に亦 す. 脱ガス処理は $26 \mathrm{~min} て ゙$ 終厂し, それ以降は溶鋼中 水素濃度はほとんど変化せず一走である。

脱ガス処理終了後に得られた $n=6$ の分析值の偏差 は次のとおりであった。

$[\mathrm{H}]=1.03 \pm 0.054(\mathrm{ppm})$

このとき相対標準偏差（R.S. D. ) は 5.25\%であり, 实 用上十分な精度であった。 


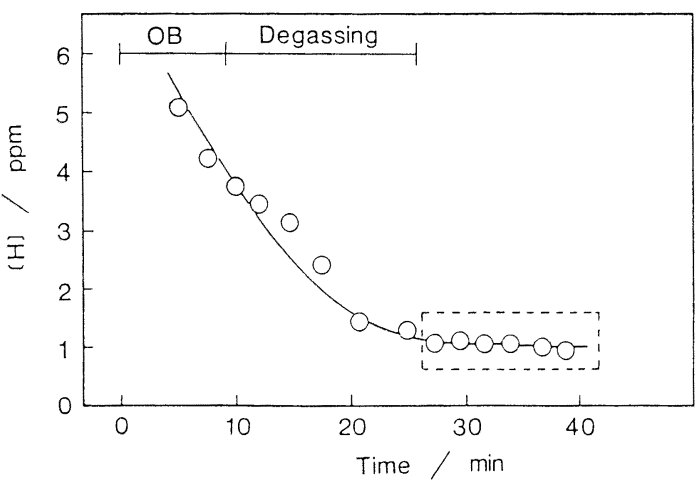

Fig. 7. Change with time in hydrogen content after degassing.

本法はピンサンプリング法のような武料採取を必要と しないため，分析時䦌が人宿に知縮されている。ピンサ ンプリング法では分析結果が得られるまでに $10 \mathrm{~min}$ 以 ト:を要するが, 本法の分析所要時閶は約 $2.5 \mathrm{~min}$ である. この分析時㓦の人半はガスクロマトグラフによるガス成 分分離に要しているが, ガス成分分離が不要で, 迅速性 に優れた検壮器を導入することでさらに分析時閏の短縮 が川能である。現在，約 $30 \mathrm{~s}$ の遅机時间のみで連続分 析川能な半䆃体ガスセンサーの適用を検澍中である ${ }^{13)}$. さらに，本法の分析操作は簡単で熟練を要しないため, 無人化できる临能性もある。

\section{5. 結言}

浴鋼中水素のオンライン・リアルタイム分析法の確立。 を目的に，浴罁中に不活性ガスを吹き込み，吹き込んた ガスと浴制との父液斗衡に基づいて水素濃度を測定する お法を開発し，実烟試験を行ってきた。実操業下の RH 脱ガス処理プロセスに扔いて種々の検㨽を行った結果, 以下の占を明らかにした。
(1)溶鋼へ浸淇する酎火物製プローブの材啠には $\mathrm{Al}_{2} \mathrm{O}_{3}-\mathrm{SiC}$ 系が最適であった。また，浴铜へのガス吹

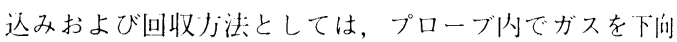
きに吹き出し，プローブは部より㺫收するう式が牧適で あった。

( 2 ) 溶鋼中水素と汗衡に涬したガスを回收するために 最適なガス吹込み条俳は以下のと抢りであった。

(1) Ar ガス吹込み流星 : $1000 \mathrm{ml} / \mathrm{min}$

(2) Ar ガス吹込み樑さ：40 80 mm

(3) 本法の分析听要時间は $2.5 \mathrm{~min} /$ 以であり, 分析 精度は溶鋼中水素濃度約 $1 \mathrm{ppm}$ に扔いて㥊対標潐偏差 約 $5 \%$ であった。

（4）本法を用いることで，涏米に比べ精度，正確さに 優れた水素分析做を进速に得ることができるようにな

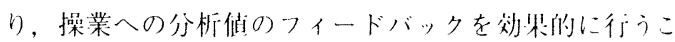
とができる。

\section{文献}

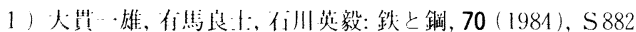

2) 人坪孝寺, 川瀨中久, 川峪修; 後滕俊助: 鉄と艄, 71 (1985), A 141

3 ) T. Ohtsubo, H. Kawase: and S. Yamazaki: Hydrogen Embrittlement, Prevention and Control, ASTM STP 962 (1987), p. 105

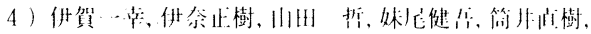

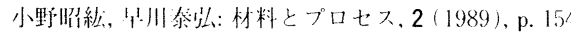

5 ) C. E. Ransi.fy, D. E. J. Tal.boT and H. C. Bariouw: J. Inst. Met., $86(1957-58)$, p. 212

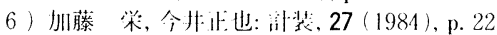

7 ) J. Pilisskirs, R. Maks and E. Vanchitoovin: Stahl Eisen, 134 (1988), p. 108

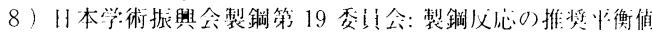
改沙增補 (1984)

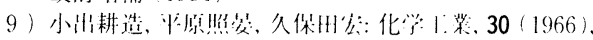
p. 712

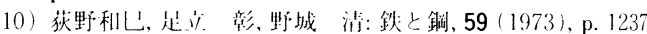

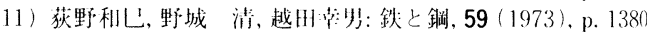

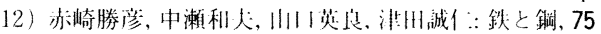
(1989), p. 175

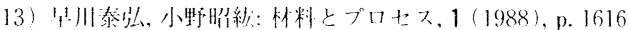

